\title{
Hydrologic variation during the last 170,000 years in the southern hemisphere tropics of South America
}

\author{
Sherilyn C. Fritz, ${ }^{\mathrm{a}, \mathrm{b}, *}$ Paul A. Baker, ${ }^{\mathrm{c}, \mathrm{d}}$ Tim K. Lowenstein, ${ }^{\mathrm{e}}$ Geoffrey O. Seltzer, ${ }^{\mathrm{f}}$ \\ Catherine A. Rigsby, ${ }^{\mathrm{g}}$ Gary S. Dwyer, ${ }^{\mathrm{c}}$ Pedro M. Tapia, ${ }^{\mathrm{a}}$ Kimberly K. Arnold, ${ }^{\mathrm{c}}$ \\ Teh-Lung $\mathrm{Ku},{ }^{\mathrm{h}}$ and Shangde Luo ${ }^{\mathrm{h}}$

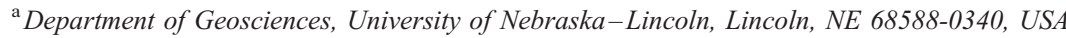 \\ ${ }^{\mathrm{b}}$ School of Biological Sciences, University of Nebraska-Lincoln, Lincoln, NE 68588-0340, USA \\ ${ }^{\mathrm{c}}$ Division of Earth and Ocean Sciences, Duke University, Durham, NC 27708-0227, USA \\ ${ }^{\mathrm{d}}$ Nicholas School of the Environment, Duke University, Durham, NC 27708-0227, USA \\ ${ }^{\mathrm{e}}$ Department of Geological Sciences and Environmental Studies, State University of New York at Binghamton, Binghamton, NY 13902, USA \\ ${ }^{\mathrm{f}}$ Department of Earth Sciences, Syracuse University, Syracuse, NY 13244, USA \\ ${ }^{\mathrm{g}}$ Department of Geology, East Carolina University, Greenville, NC 27858, USA \\ ${ }^{\mathrm{h}}$ Department of Earth Sciences, University of Southern California, Los Angeles, CA 90089, USA
}

Received 13 March 2003

\begin{abstract}
Despite the hypothesized importance of the tropics in the global climate system, few tropical paleoclimatic records extend to periods earlier than the last glacial maximum (LGM), about 20,000 years before present. We present a well-dated 170,000-year time series of hydrologic variation from the southern hemisphere tropics of South America that extends from modern times through most of the penultimate glacial period. Alternating mud and salt units in a core from Salar de Uyuni, Bolivia reflect alternations between wet and dry periods. The most striking feature of the sequence is that the duration of paleolakes increased in the late Quaternary. This change may reflect increased precipitation, geomorphic or tectonic processes that affected basin hydrology, or some combination of both. The dominance of salt between 170,000 and 140,000 yr ago indicates that much of the penultimate glacial period was dry, in contrast to wet conditions in the LGM. Our analyses also suggest that the relative influence of insolation forcing on regional moisture budgets may have been stronger during the past 50,000 years than in earlier times.
\end{abstract}

(C) 2003 University of Washington. All rights reserved.

Keywords: Quaternary; Paleohydrology; Paleoclimate; Diatoms; Oxygen isotopes; Evaporites; Tropics; South America; Andes; Altiplano

\section{Introduction}

Understanding the patterns and forcing of climate variation at orbital, millennial, and submillennial time scales requires long well-dated time series of paleoclimatic data, particularly from areas of the globe thought to be critical centers of climatic action. Changes in the rate of meridional overturning ocean circulation (Stocker, 2000), tropical production of carbon dioxide, methane, and especially water vapor (Blunier et al., 1995; Wielicki et al., 2002), and

\footnotetext{
* Corresponding author. Department of Geosciences, University of Nebraska-Lincoln, Lincoln, NE 68588-0340. Fax: +1-402-472-4917.

E-mail address: sfritz2@unl.edu (S.C. Fritz).
}

modes of tropical ocean-atmosphere interaction (Cane and Clement, 1999; Peterson et al., 2000) have been posited as sources of intrinsic climate variability. Likewise, variations in solar radiation may have externally forced climate on both orbital (Berger, 1978) and suborbital (Bond et al., 2001) time scales. The relative roles of these different components of the climate system are still unclear; moreover, their respective contributions may have changed with time (Gallup et al., 2002; McManus et al., 1999).

The South American tropics are an important component of the tropical climate system, and accordingly the number of published paleoclimatic records from this region has increased in recent years (e.g., Baker et al., 2001a, 2001b; Betancourt et al., 2000; Bobst et al., 2001; Maslin and Burns, 2000; Mayle et al., 2000; Peterson et al., 2000; 
Seltzer et al., 2000). Even so, very few continental records extend to intervals significantly earlier than the last glacial maximum (LGM), approximately 20,000 yr ago. One prominent exception is a pollen sequence spanning over a million years from Sabana de Bogata in Columbia (Hooghiemstra et al., 1993), which shows a strong relationship between vegetation change and orbital forcing, although it is unclear what environmental factor(s) (e.g., $\mathrm{CO}_{2}$, temperature, precipitation) affected the vegetation changes. The limited number of long continental records makes it difficult to evaluate (1) whether the tropics have experienced the same high-frequency climate variation evident in ice cores from northern high latitudes and some marine sediment cores, (2) whether climate during the LGM and subsequent deglaciation are similar to previous glacial-interglacial periods, and (3) what the role of the South American tropics might have been in affecting atmospheric gas concentrations. Here, we present a well-dated 170,000-yr time series of hydrologic variation from Salar de Uyuni in tropical South America that

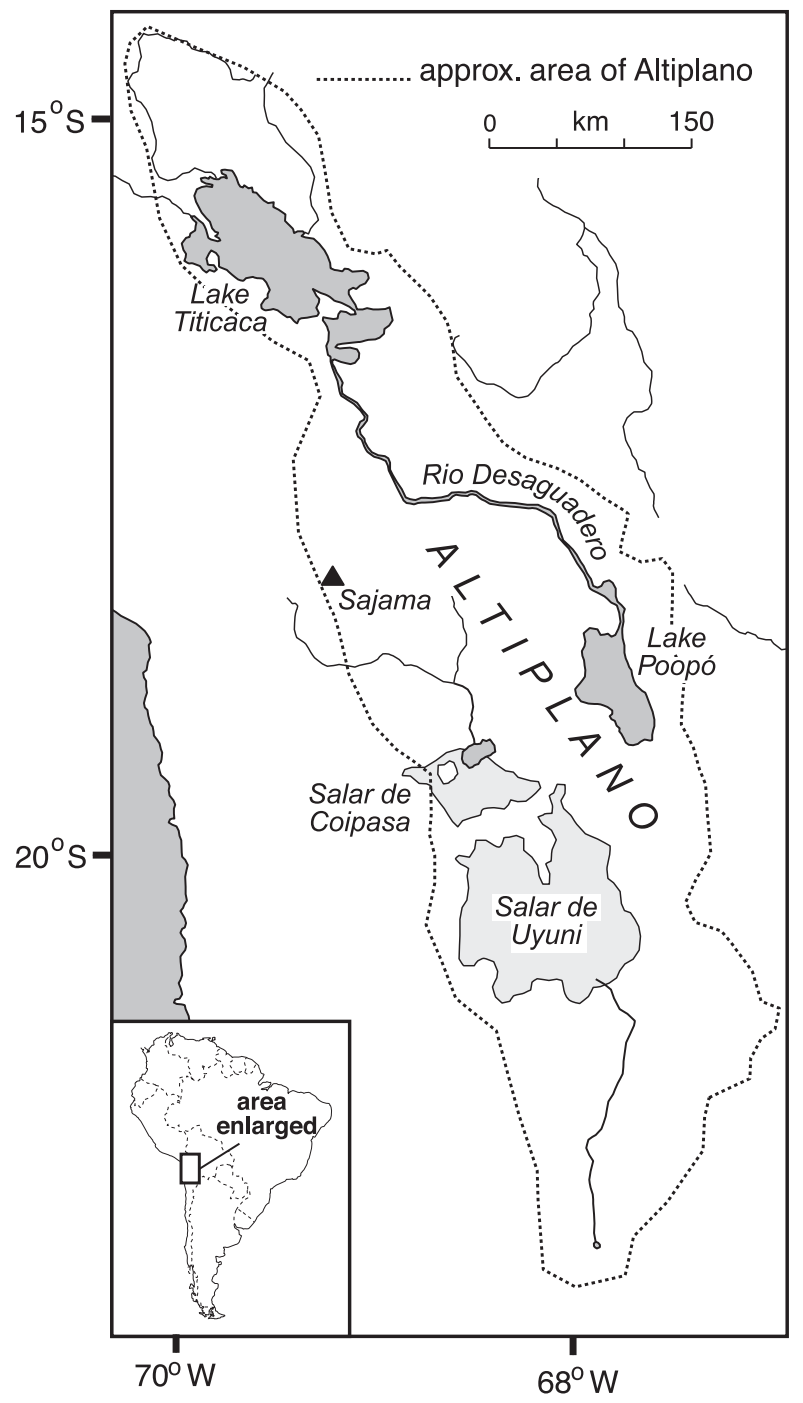

Fig. 1. Map of the Altiplano, showing the Salar de Uyuni, Lake Titicaca, Sajama, and major rivers. extends from modern times through most of the penultimate glacial period (marine oxygen isotope stage 6, MIS 6).

The Salar de Uyuni $\left(20^{\circ} \mathrm{S} 68^{\circ} \mathrm{W}, 3653 \mathrm{~m}\right.$ above sea level), the world's largest salt flat, is located on the Bolivian Altiplano, a high-elevation plateau between the eastern and western cordilleras of the central Andes (Fig. 1). Water inputs to the modern Salar are from local precipitation and river runoff. Today, Lake Titicaca overflows southward via the Rio Desaguadero into Lago Poopo. During extremely wet periods of the past, Lago Poopo discharged into Salar de Coipasa and Salar de Uyuni, thus establishing a hydrologic connection between the northern and central Altiplano. The Salar de Uyuni is underlain by hundreds of meters of sediment, which consist of muds, deposited in perennial lakes, that alternate with salts (halite and gypsum), deposited in shallow hypersaline lakes or salt pans. This sequence of muds and salts registers respectively, wet versus dry periods and provides a long-term record of the hydrologic history of the basin. We previously reported on the timing of wet and dry periods in the ${ }^{14} \mathrm{C}$-dated portion of the Salar de Uyuni record, spanning the past 50,000 years (Baker et al., 2001a). Here, we apply the U/Th isochron method (Ku, 2000), which allows us to date salt intervals accurately over the past 170,000 yr. Furthermore, we present new paleobiotic and geochemical data that enable us to estimate the water depth of the paleolakes and precipitation variation through time.

\section{Climatic setting}

Modern mean annual temperature at Salar de Uyuni is $5{ }^{\circ} \mathrm{C}$, mean annual precipitation is about $150 \mathrm{~mm} \mathrm{yr}^{-1}$, and potential evapotranspiration exceeds precipitation. The majority of precipitation over the basin occurs during December through March as part of the South American summer monsoon (Zhou and Lau, 1998). In the austral summer, the easterly trade winds strengthen in the Atlantic, which increases moisture transport from the Atlantic onto the continent. Moisture is then advected in low-level winds across the Amazon, then southward down the eastern flank of the Andes into an intensifying surface low, known as the Gran Chaco low, located immediately east of the Altiplano. Near the eastern slope of the Andes, convective heating lifts this moist air from the lowlands onto the Altiplano. The intense summer heating of the continental interior and the resultant latent heat release by precipitation over the Amazon and Altiplano give rise to the Bolivian high, a warmcore anticyclone in the upper troposphere that is centered above the Altiplano (Lenters and Cook, 1997). The position and strength of the Bolivian high has been linked to changes in equatorial Pacific sea-surface temperatures associated with ENSO and is thought to modulate the easterly penetration of winds bringing moisture from the Amazon onto the Altiplano (Garreaud et al., 2003; Vuille et al., 2000), thereby affecting interannual precipitation variation on the 
Altiplano. On decadal and longer timescales, it is speculated that changes in tropical-Atlantic meridional sea-surfacetemperature gradients also force precipitation variability in the Amazon (Nobre and Shukla, 1996), on the Altiplano (Baker et al., 2001a), and in the South Atlantic convergence zone (Robertson et al., 2000).

\section{Methods}

\section{Field}

In June 1999, we drilled and cored the uppermost $220.6 \mathrm{~m}$ of sediment in the central portion of the Salar de Uyuni $\left(20^{\circ} 14.97^{\prime} \mathrm{S}, 67^{\circ} 30.03^{\prime} \mathrm{W}\right)$. Recovery was $\sim 85 \%$, and thus some gaps occur in the otherwise continuous sediment sequence caused by loss of material associated with fluid circulation in drilling. Following drilling, the stud-cased hole was logged at $10-\mathrm{cm}$ intervals to a depth of $188.7 \mathrm{~m}$ subbottom with a tool that measures natural gamma radiation (Fig. 2).

\section{Dating}

AMS radiocarbon measurements were made on the total organic carbon content of mud or salt from 17 samples in the uppermost $31 \mathrm{~m}$ of core. Dates were calibrated using Calib 4.3 (Stuiver et al., 1998) for ages $<24,000 \mathrm{cal}$ yr B.P. and the quadratic equation of Bard et al., 1998 for older samples. Ages are corrected for stableisotope fractionation but are not adjusted for reservoir effects. The reservoir effect for the paleolakes in the Uyuni basin is not known but is assumed to be small, because there is little carbonate rock in the watershed, and because during the major lake phases, the large volume of inflow from Lake Titicaca and the large surface area to volume ratio of the paleolakes would have minimized the contribution of non-atmospheric carbon (for further details see Baker et al., 2001a, and Sylvestre et al., 1999). The Useries disequilibrium method, which can be used to date materials up to $\sim 300,000 \mathrm{yr}(\mathrm{Ku}, 2000)$, was used to date 14 samples from salt units to a depth of $116.5 \mathrm{~m}$. Salts for U-series dating were screened by thin-section examination to avoid samples that had undergone diagenetic modification and to choose samples with minimal development of shallow subsurface halite cement. Age estimates for the core sequence are based on a fourth order polynomial equation fit to the combined radiocarbon and U-Th ages in the upper $100 \mathrm{~m}$ of core (Fig. 3).

\section{Stratigraphy}

The core was measured and described in the field and subsequently described in more detail in the laboratory. One hundred thin sections of the evaporites were prepared for petrographic studies, using a diamond wire saw. X-ray diffraction was used for routine mineral identification.

\section{Diatoms}

Samples from mud units were processed for diatom analysis by treatment with $10 \% \mathrm{HCl}$ to dissolve carbonates, followed by a cold hydrogen-peroxide treatment to oxidize organic matter. The prepared samples were rinsed repeatedly to remove oxidation by-products. Slurries of the prepared sample were dried onto coverslips, and the coverslips were mounted onto slides with Naphrax. Diatoms were counted at 100x on a Leica DMRX microscope with differential interference contrast. Where possible, at least 300 diatom valves were counted. In samples where diatom concentration was low, at least one whole slide was scanned for diatom enumeration. Diatom abundance is expressed as a percentage relative to the total number of counted valves.

\section{Isotopes}

Stable oxygen isotopic ratios of the carbonate fraction of mud samples were measured in the stable isotope laboratory at North Carolina State University. The precision of the analysis is $\pm 0.06 \%$ o based on replicate analyses of internal

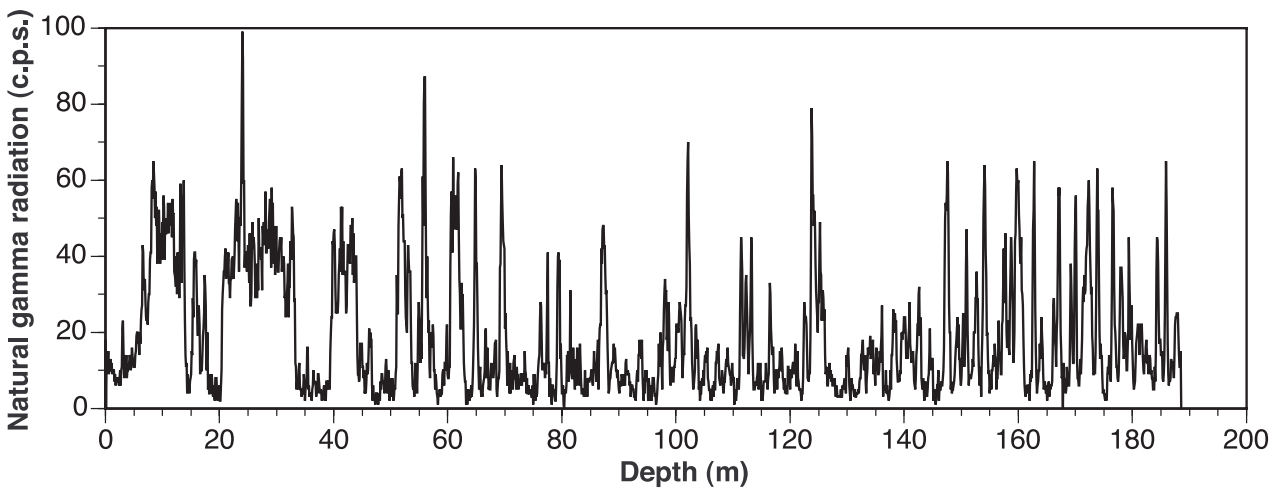

Fig. 2. Log of natural gamma radiation (counts per second) in the Salar de Uyuni drill hole for the entire 188-m logged sequence. 


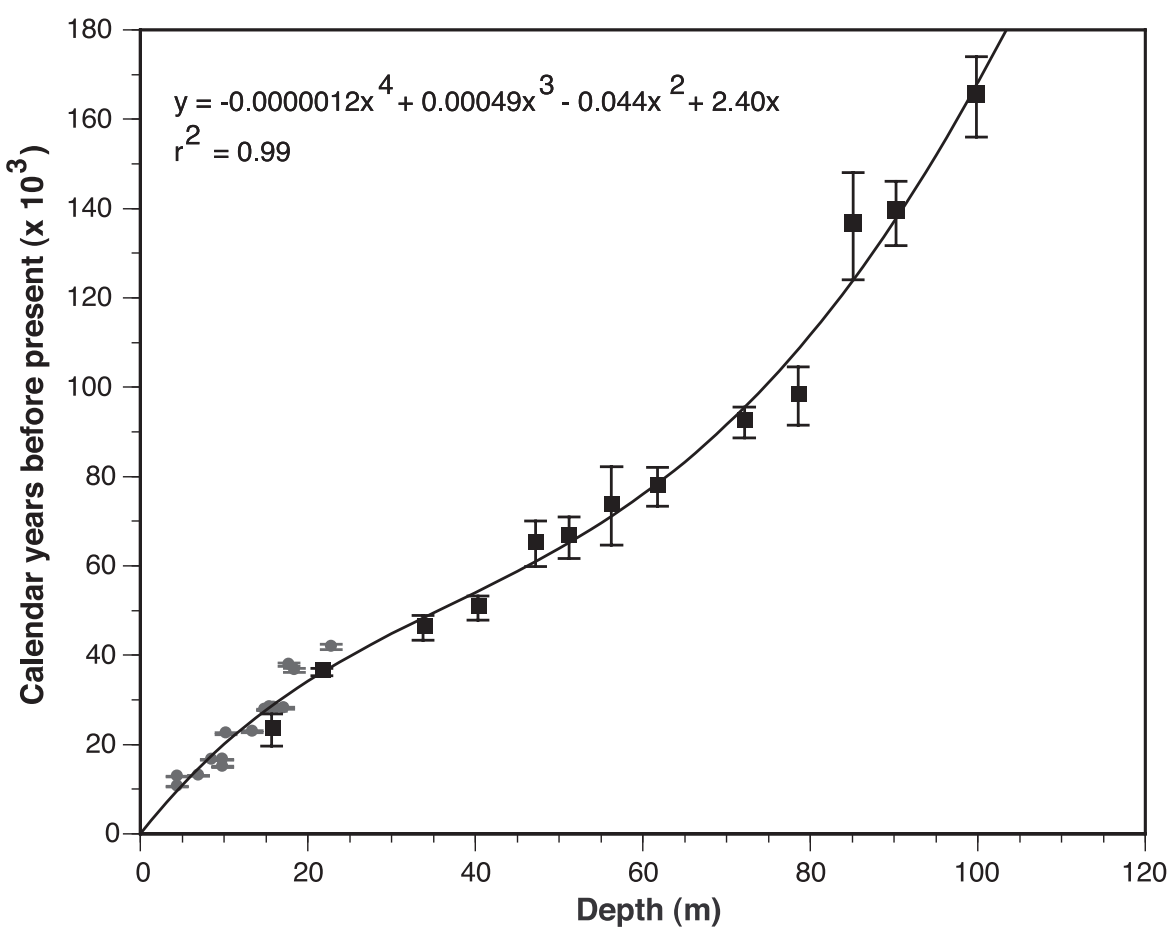

Fig. 3. Relationship between core depth and calendar age as established by accelerator mass spectrometry ${ }^{14} \mathrm{C}$ analysis of organic carbon (gray circles) and U/ Th series disequilibrium dating of salts using the isochron method (larger black squares). Error bars represent $1 \sigma$.

standards. In preparation for analysis, all samples were rinsed in reagent-grade water to remove soluble salts.

\section{Results}

\section{Chronology}

The U-series ages indicate that the upper $100 \mathrm{~m}$ of the core spans approximately the past 170,000 years (Table 1).
A date of $276,000( \pm 21,000) \mathrm{yr}$ on salt at $116 \mathrm{~m}$ is near the limit of the U-series method and indicates that accumulation rates declined sharply below $100 \mathrm{~m}$. As a result, we focus here on the uppermost $100 \mathrm{~m}$. Our two uppermost U-series dates overlap with the radiocarbon chronology (Fig. 3). The youngest of these U-series ages $(23,000 \pm 3600 \mathrm{yr}, 15.65 \mathrm{~m})$ is less than the bracketing radiocarbon ages (Table 1), but has a relatively large error, which arises from uncertainties in the detrital ${ }^{230} \mathrm{Th}$ correction. Thus, the radiocarbon chronology in this zone

Table 1

Radiocarbon ages determined by accelerator mass spectrometry (AMS) on the total organic carbon of the mud and U-series disequilibrium dating of the salts using the isochron method

\begin{tabular}{|c|c|c|c|c|c|c|}
\hline $\begin{array}{l}\text { Sample number } \\
\text { NSRL }\end{array}$ & $\begin{array}{l}\text { Sample depth } \\
\text { (m) }\end{array}$ & $\begin{array}{l}\delta{ }^{13} \mathrm{C} \% o \\
\mathrm{PDB}\end{array}$ & $\begin{array}{l}\text { Radiocarbon age } \\
( \pm 1 \sigma){ }^{14} \mathrm{C} \text { yr B.P. }\end{array}$ & $\begin{array}{l}\text { Calibrated age }( \pm 2 \sigma) \\
\text { cal yr B.P. }\end{array}$ & $\begin{array}{l}\text { Sample depth } \\
(\mathrm{m})\end{array}$ & $\begin{array}{l}\mathrm{U} / \text { Th age }( \pm 1 \sigma) \\
(\mathrm{yr})\end{array}$ \\
\hline 11511 & 6.91 & -16.0 & $10,980 \pm 55$ & $12,659(12,993) 13,162$ & 15.65 & $23,200 \pm 3600$ \\
\hline 10884 & 8.47 & -13.9 & $13,800 \pm 100$ & $16,067(16,560) 17,091$ & 21.65 & $36,200 \pm 800$ \\
\hline 11509 & 9.77 & -13.9 & $13,840 \pm 65$ & $16,142(16,606) 17,109$ & 33.75 & $46,100 \pm 2800$ \\
\hline 10885 & 10.20 & -13.6 & $18,920 \pm 250$ & $21,575(22,452) 23,406$ & 40.30 & $50,500 \pm 2700$ \\
\hline 10886 & 13.35 & -13.4 & $19,250 \pm 190$ & $22,027(22,832) 23,730$ & 47.2 & $64,900 \pm 5100$ \\
\hline 10887 & 15.14 & -13.5 & $23,600 \pm 190$ & 27,750 & 51.15 & $66,300 \pm 4700$ \\
\hline 10888 & 15.72 & -13.4 & $24,100 \pm 200$ & 28,20 & 56.25 & $73,400 \pm 8800$ \\
\hline 10889 & 16.22 & -13.3 & $24,000 \pm 800$ & 28,210 & 61.75 & $77,700 \pm 4400$ \\
\hline 10890 & 17.09 & -13.4 & $23,900 \pm 190$ & 28,100 & 72.10 & $92,100 \pm 3500$ \\
\hline 10891 & 17.70 & -15.9 & $32,600 \pm 410$ & 37,830 & 78.55 & $98,000 \pm 6500$ \\
\hline 10892 & 18.37 & -15.5 & $31,500 \pm 480$ & 36,630 & 85.10 & $136,000 \pm 12,000$ \\
\hline \multirow[t]{3}{*}{10893} & 22.78 & -17.6 & $36,300 \pm 590$ & 41,840 & 90.20 & $138,900 \pm 7200$ \\
\hline & & & & & 99.80 & $165,000 \pm 9000$ \\
\hline & & & & & 116.50 & $276,000 \pm 21,000$ \\
\hline
\end{tabular}

Radiocarbon ages were calibrated using Calib 4.3 (Stuiver et al., 1998) for ages $<20,000{ }^{14} \mathrm{C}$ yr B.P. and the equation of Bard et al. (1998) for older dates. Ages derived with Calib 4.3 show the calibrated age in parentheses and the $2 \sigma$ range. 
is more likely correct. The U-series age estimate at $21.65 \mathrm{~m}$ $(36,200 \pm 800 \mathrm{yr})$ is also less than adjacent radiocarbon ages. This sample had a low detrital content and hence is better constrained, which suggests that the adjoining radiocarbon ages may be too old, because of reworking of old carbon or because of a reservoir effect that is not accounted for. Despite these discrepancies, overall there is remarkably good agreement between the two dating methods, and given our emphasis here on millennial trends and the long-term record, we feel that the chronology is robust.

Our U-series ages cast doubt on a single $\mathrm{Ar}-\mathrm{Ar}$ date of $191,000 \pm 5000 \mathrm{yr}$ reported at a volcanic ash at $46 \mathrm{~m}$ below the Salar surface in a previous study (Fornari et al., 2001). This ash was not recovered in our drilling, because of the loss of fine sediments in this interval caused by fluid circulation. However, the two cores are from approximately the same location on the Salar and have nearly identical stratigraphies. Our U/Th chronology places the interval at $46 \mathrm{~m}$, which likely contained the ash, at about 59,000 yr. Although sources of error in the ArAr age estimate are not readily apparent, the well-constrained U-series ages suggests that the $\mathrm{Ar}-\mathrm{Ar}$ date is incorrect or alternatively not indicative of the age of deposition of the tephra.

\section{Stratigraphy}

We distinguish three major depositional environments in the Salar de Uyuni core based on sedimentary structures (Fig. 4). Strata characterized as "perennial lake" are mud units from lakes that ranged from shallow to deep and relatively fresh to saline (based on diatom analysis; see below). The mud units vary from massive to laminated and in grain size and concentrations of carbonates (calcite, as mud and as rod-shaped fecal pellets), gypsum crystals, sulfides, organic material, and ostracode and siliceous remains. Strata characterized as "shallow perennial saline lake" and "salt pan" are salt units that are distinguished based on salt textures. The bedded salts are dominantly halite, with laminae and thin beds of gypsum crystals and carbonate mud and pellets. Halite layers commonly contain well-preserved "chevron" textures outlined by fluid inclusion-banded crystals, as well as sorted crystal plates, rafts, and hoppers, all diagnostic of precipitation in a shallow perennial saline lake (Smoot and Lowenstein, 1991). Other halite units are nonbedded massive cements typical of saline pan deposits, such as present-day Salar de Uyuni, where extensive recycling by dilute floodwaters destroys primary halite and produces porous crusts that are later cemented.

The downhole natural gamma log from the cased drill hole provides the most complete record of the Salar de Uyuni stratigraphy, because sediment recovery in drilling was only about $85 \%$ complete. The gamma record differentiates mud units, which contain abundant radiogenic $\mathrm{K}, \mathrm{U}$, and Th, from salts, which are largely nonradioactive (Fig. 2). When plotted on an age scale (Fig. 4), it is apparent that the uppermost mud units are more persistent than those lower in the sequence. Furthermore, salt textures suggest that most of the salts above $70 \mathrm{~m}$ were deposited in shallow perennial saline lakes, whereas below this, the salts are characteristic of salt pan environments.

\section{Diatom stratigraphy}

The diatom assemblage of the Salar de Uyuni core is diverse (Fig. 5), and preservation is highly variable. In the uppermost major mud unit (9.75-18.42 m), diatoms are not preserved in some samples, but those samples containing diatoms are dominated by planktic species (Fig. 6a), with

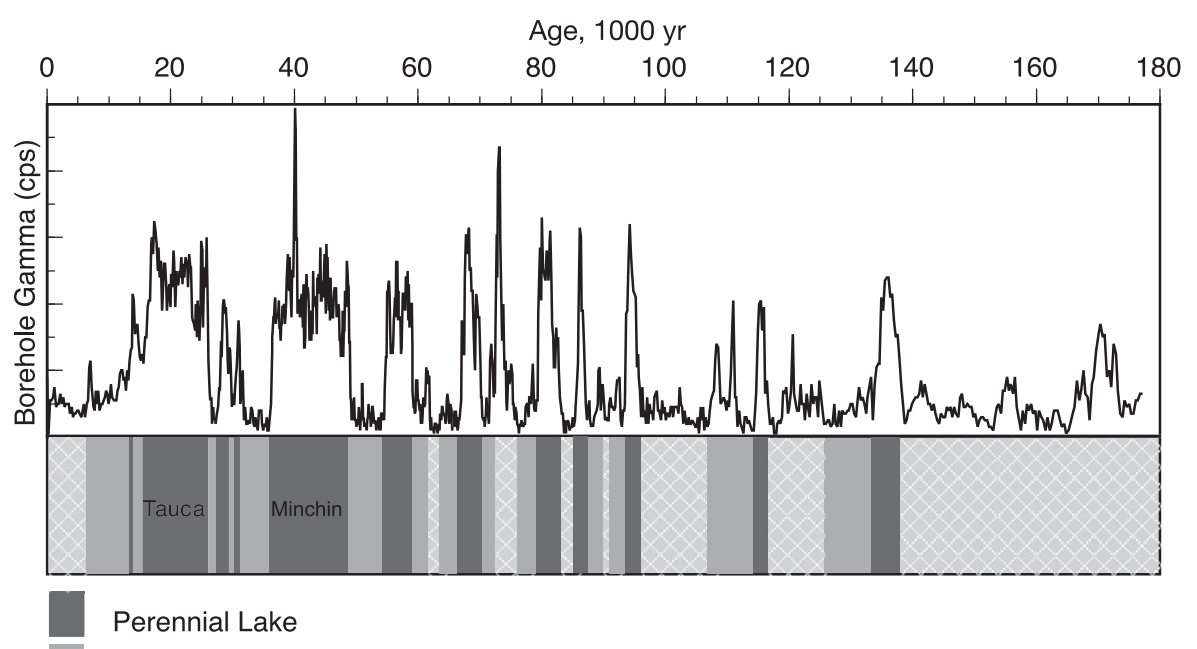

Shallow Perennial Saline Lake

Salt Pan

Fig. 4. Generalized stratigraphy of the upper $100 \mathrm{~m}$ of the Salar de Uyuni core displayed versus calendar age. See text for additional details. 


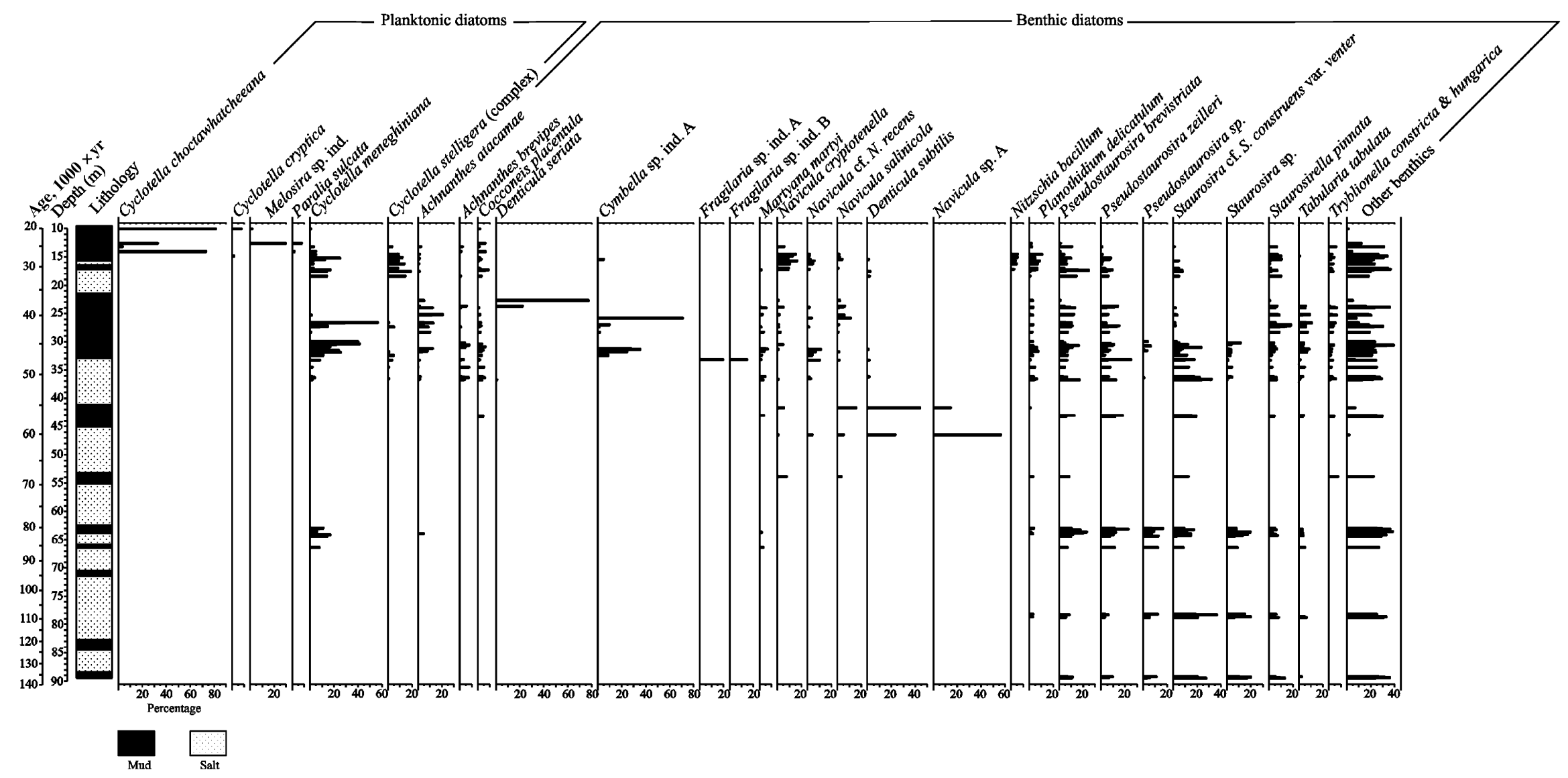

Fig. 5. Stratigraphy (percent abundance) of the common $(>5 \%)$ diatom taxa in the upper $100 \mathrm{~m}$ of the Salar de Uyuni core. Samples were taken from all mud units and from lenses of mud within some of the salt units. Note that some of the mud units, particularly below $65 \mathrm{~m}$, were barren of diatoms (see Fig. 6). 

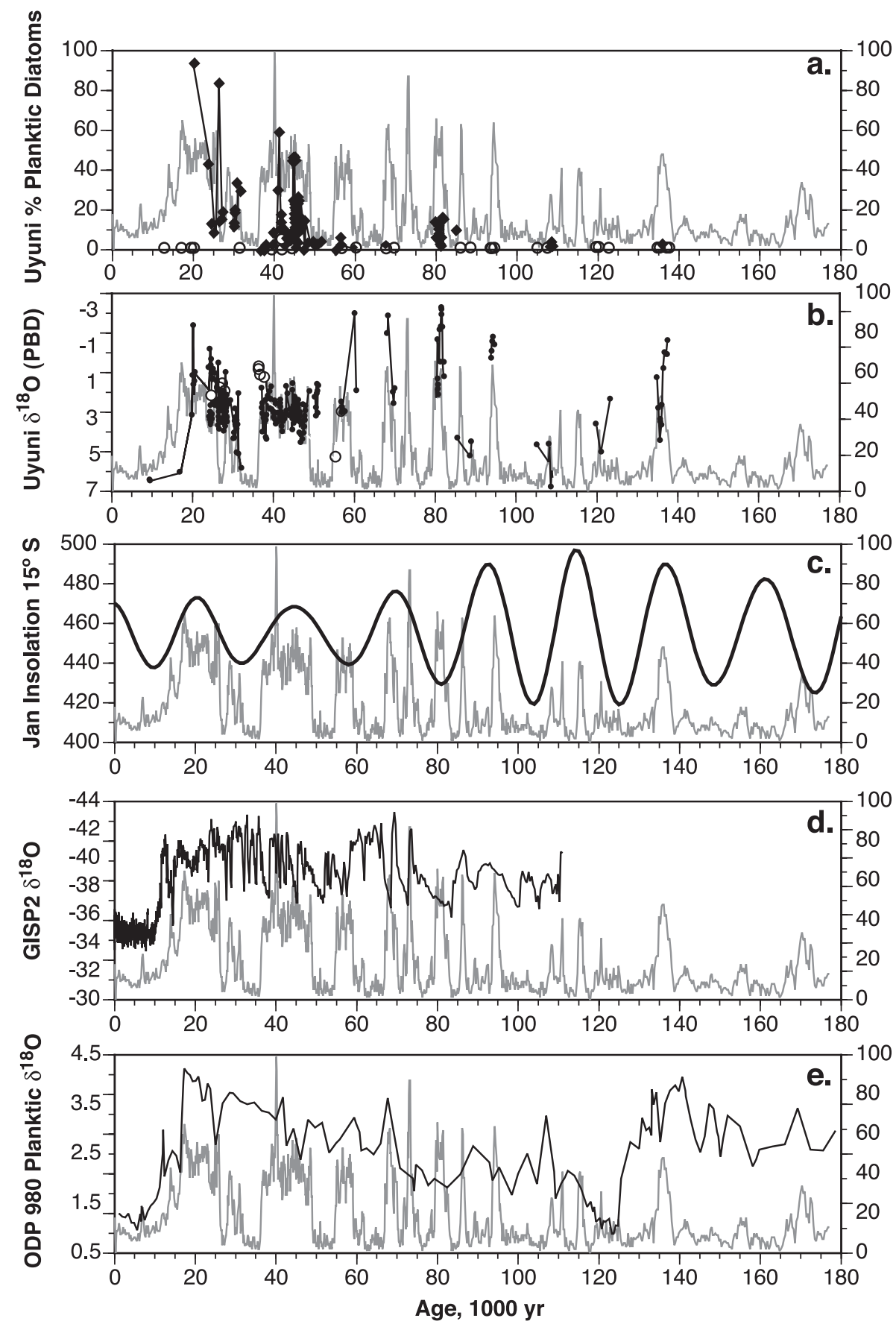

Fig. 6. Changes in natural gamma radiation (gray line) in the upper $100 \mathrm{~m}$ of the Salar de Uyuni core (right-hand vertical axis), displayed versus calendar age, compared with biotic and geochemical measurements in the mud units and with other paleoclimatic time series. (a) Percentage of planktic (free-floating) diatoms in lacustrine muds (solid diamonds); the remainder of the diatoms are benthic (shallow-water) taxa. Samples without any preserved diatoms are indicated by open circles. (b) $\delta^{18} \mathrm{O}$ of authigenic carbonate in the mud units; open circles are measurements on lithified crusts, (c) calculated January insolation at $15^{\circ} \mathrm{S}$ (Berger, 1978), (d) GISP2 $\delta^{18} \mathrm{O}$ of the ice (Grootes and Stuiver, 1997), and (e) $\delta^{18} \mathrm{O}$ of planktic foraminifera in North Atlantic site ODP980 (McManus et al., 1999).

moderate $(20-40 \%)$ percentages of benthic taxa. The saline species, Cyclotella choctawatcheeana, is dominant in several samples in this unit, and Cyclotella meneghiniana and C. stelligera, which tolerate a range of salinities, dominate the other samples. The second youngest major mud unit $(22.6-33.38 \mathrm{~m})$ has high percentages of planktic species (primarily C. meneghiniana) in most levels, together with a mixture of benthic diatoms, some salinity indifferent and others characteristic of saline waters (Sylvestre et al., 2001). Denticula seriata dominates the uppermost samples in this section, which suggests increased salinity just prior to precipitation of the overlying salts. The third major mud unit $(41.6-46.5 \mathrm{~m})$ is distinct, because of the high percentages of Denticula subtilis, Navicula salinicola, and Navi- 
cula sp. A, which together suggest shallow moderately saline waters. A mixture of generalist benthic taxa, particularly in the genera Pseudostaurosira, Staurosira, and Staurosirella, dominate the diatom-bearing mud units below $50 \mathrm{~m}$. Many of these species are common in freshwater springs at the margin of the contemporary Salar (Sylvestre et al., 2001). Planktic diatoms are generally rare $(<4 \%)$ in these lowermost sections, with the exception of some layers between 62.95 and $66.31 \mathrm{~m}$, where they attain up to $20 \%$. In general, diatom preservation is much poorer below $40 \mathrm{~m}$ than above, and many of the lower mud units are barren of diatoms.

\section{Isotopes}

Stable-oxygen-isotopic ratios $\left(\delta^{18} O\right)$ of lacustrine carbonates range from about -3 to $+7 \%$ (PDB) (Fig. 6b). The oldest muds of the uppermost mud unit $(\sim 32,000 \mathrm{yr})$ have $\delta^{18} \mathrm{O}$ of $+6 \%$; then values decrease to $\sim 0 \%$ just after the LGM, and then rapidly increase to $>6 \%$ coincident with evaporative drawdown of the lake. This isotopic "cycle" is driven primarily by changes in the isotopic composition of source precipitation, the post-LGM portion of which is observed in the Sajama ice core (Thompson et al., 1998), and secondarily by changing water balance of the fillingthen-desiccating paleolake. In lower mud units, mud recovery was often incomplete, and therefore we cannot generate a continuous reconstruction of the isotopic evolution of lake waters within an individual mud unit. Many of the earlier mud units have more depleted isotopic values than do the two uppermost units.

\section{Discussion}

The most distinctive feature of the Salar de Uyuni stratigraphy is that the mud units are longer in duration in the upper part of the sequence than below. The two uppermost major mud units have been identified with paleolakes Tauca $(26,000-15,000 \mathrm{cal}$ yr B.P.) and Minchin (46,000-36,000 yr) (Baker et al., 2001a), which are associated with dated paleoshorelines (Bills et al., 1994; Servant et al., 1995; Sylvestre et al., 1999). Our new extended record indicates that these were also the two longest lacustrine intervals in the entire dated sequence. Fossildiatom analysis of the muds (Figs. 5, 6a) suggests that paleolake Tauca was the deepest of the paleolakes, as indicated by intervals with the highest percentages of planktic diatoms and the dominance of Cyclotella choctawatcheeana, a planktic diatom characteristic of deep mesosaline $\left(>10 \mathrm{~g} \mathrm{~L}^{-1}\right)$ lakes and brackish marine systems (Fritz et al., 1993; Prasad, 1990). The highest outcropping paleoshorelines in the basin demonstrate that paleolake Tauca reached $140 \mathrm{~m}$ above the modern Salar (Bills et al., 1994). Stable-oxygen-isotopic values of carbonates in the Tauca unit (Fig. 6b) are surprisingly low for a closed-basin saline lake, a result of input of high amounts of isotopically depleted precipitation and inflow. Modern precipitation near the Salar averages $-16 \%$ (SMOW) (Baker, unpublished data), and 20th-century snowfall on the nearby Sajama volcano averaged $-17.5 \%$ (SMOW) (Thompson et al., 1998). However, during the LGM, when the Altiplano was wetter than today (Baker et al., 2001a, 2001b), the $\delta^{18} \mathrm{O}$ of precipitation was considerably more depleted, averaging $-22 \%$ in the Sajama ice core (Thompson et al., 1998). Thus, precipitation and local inflow to paleolake Tauca would have been $\sim 4 \%$ lower than modern values. In the LGM, waters of Lake Titicaca were also more depleted due to more depleted values in precipitation and a greatly increased throughflow. We calculated previously that lake waters were about $-13 \%$, which is $9 \%$ more negative than today (Cross et al., 2001). At that time, outflow from Lake Titicaca was many times its modern value and likely contributed a large fraction of the input that sustained the deep paleolake in the Uyuni basin.

The diatom composition of paleolake Minchin muds suggests that lake depths varied from moderate, with high proportions of the planktic Cyclotella meneghiniana and $C$. stelligera, to shallow, with a diverse flora of benthic species. Isotopic analyses of authigenic carbonates of paleolake Minchin show fluctuations of up to $4 \%$ due to variations in the isotopic concentration of source precipitation and/or hydrologic mass balance.

Prior to $\sim 50,000 \mathrm{yr}$, the hydrology of the Uyuni basin seems to have been fundamentally different. The thinner mud units and dominance of halite indicate that relatively fresh perennial lakes were short-lived and less frequent. In contrast to the upper part of the core, petrographic textures and fabrics of the salts indicate that many were deposited in predominantly dry salt pans rather than shallow hypersaline lakes. Similarly, the dominance of benthic diatoms in the lower mud units (Figs. 5, 6a) suggests that older paleolakes were relatively shallow. On the other hand, the $\delta^{18} \mathrm{O}$ of carbonate muds in many of the older lacustrine units is surprisingly low (Fig. 6b), especially given the diatombased inference of shallow waters. It is possible that the water temperature was much higher in these shallow lakes at the time of carbonate formation, but the approximately $15^{\circ} \mathrm{C}$ warmer conditions required seem improbable. A more likely explanation is that overflow from Lake Titicaca to the Salar de Uyuni was reduced or absent prior to $\sim 50,000 \mathrm{yr}$. In that case, shallow paleolakes would have formed during sustained wet periods entirely from direct precipitation and local runoff (with more negative isotopic values than Lake Titicaca overflow).

Two mechanisms can account for a reduction or absence of overflow from Lake Titicaca to the central Altiplano in the earlier part of the record. One explanation is regional climatic change, and there is limited evidence to suggest a major reduction in effecive moisture in the central Altiplano prior to 50,000 yr. At the Salar de Atacama $\left(23^{\circ} \mathrm{S}\right)$, efflorescent halite crusts and cements 
indicative of hyperarid conditions dominate from 325,000 to $53,000 \mathrm{yr}$, whereas bedded salts characteristic of shallow saline lakes are more common afterward (Bobst et al., 2001; Lowenstein et al., 2003). In addition, seismic reflection stratigraphy from Lake Titicaca indicates that lake levels were at least $240 \mathrm{~m}$ lower than today sometime $>50,000 \mathrm{yr}$ (D'Agostino et al., 2002). A second explanation for the pattern of less persistent and generally shallower lacustrine phases is geomorphic or tectonic alteration of basin hydrology, including the possibility that this period pre-dates complete downcutting of the Rio Desaguadero (Servant and Fontes, 1978). Lacustrine deposits in the upper Rio Desaguadero valley, just south of Lake Titicaca, have been radiocarbon-dated at ca. 40,000 cal yr B.P. (Rigsby, unpublished data) and have an elevation about $50 \mathrm{~m}$ above modern lake level. One explanation for these dated deposits is that the outlet for Lake Titicaca was south of its present location and higher in elevation at that time. In any case, this timing postdates the observed shift in Salar hydrology, which suggests that geomorphic change may not be the major driver.

Among the mud units from 140,000 to $50,000 \mathrm{yr}$, that from $\sim 85,000$ to $80,000 \mathrm{yr}$ has moderate percentages of planktic diatoms $(5-20 \%)$, as well as depleted values of $\delta^{18} \mathrm{O}$, which suggest that precipitation may have been somewhat higher than in mud units immediately pre- and postdating this. In contrast, the period from about 125,000 to $105,000 \mathrm{yr}$ has relatively enriched oxygen isotopic values, and diatoms are poorly preserved, which indicates enhanced silica dissolution likely related to elevated salinity. Where preserved, the diatoms are all benthic species. Together these data suggest low lake levels and reduced precipitation relative to other mud units and indicate that MIS 5d and 5e were relatively dry. Salt deposition characterized the majority of MIS6, particularly between 140,000 and 170,000 yr, which indicates that the climate was dry. Thus, the wet LGM is apparently not representative of all prior glacial stages in the central Altiplano.

Regardless of the cause of the directional change in the hydrology of the Salar prior to 50,000 yr, switches between muds and salts certainly reflect an alternation between times of increased and reduced effective moisture (Blodgett et al., 1997; Hastenrath and Kutzbach, 1985; Kessler, 1984). During the past 50,000 years, wet periods in the Altiplano were in phase with summer (January) insolation maxima (Baker et al., 2001a) produced by the Earth's precessional cycle (Fig. 6c), probably because high insolation enhanced the South American summer monsoon. Our extended record suggests that during earlier times, wet intervals and insolation were not as tightly coupled, although lacustrine phases were associated with most insolation maxima (Fig. 6c). We hypothesized previously that wet intervals on the Altiplano also were associated with cold periods in the North Atlantic region, possibly because of the impact of tropical seasurface temperature gradients on moisture advection into the continent (Baker et al., 2001a, 2001b). Based on our expanded time series from the Salar, the wetter periods of the past 70,000 years occurred during times of cold North Atlantic temperatures (Figs. 6d, 6e), but prior to that time the relationship is not as coherent. Thus, the data suggest that the relationship between moisture balance in the South American Altiplano and major forcing factors may have changed with time.

\section{Acknowledgments}

We thank O. Ballivian, J. Bohorquez, N. Bacher, and C. Veliz for assistance with planning and field work and acknowledge the assistance of the Autoridad Autonoma de Lago Titicaca, Peru/Bolivia. We also thank K. Menking and D. Rodbell for thoughtful reviews of the manuscript and $\mathrm{H}$. Lintott for drafting Fig. 1. This work was supported by U.S. National Science Foundation (Earth Systems History Program) grants to SCF, PB, TL, and GOS.

\section{References}

Baker, P.A., Rigsby, C.A., Seltzer, G.O., Fritz, S.C., Lowenstein, T.K., Bacher, N.P., Veliz, C., 2001a. Tropical climate changes at millennial and orbital timescales in the Bolivian Altiplano. Nature 409, 698-701.

Baker, P.A., Seltzer, G.O., Fritz, S.C., Dunbar, R.B., Grove, M.J., Tapia, P.M., Cross, S.L., Rowe, H.D., Broda, J.P., 2001b. The history of South American tropical precipitation for the past 25,000 years. Science 291, 640-643.

Bard, E., Arnold, M., Hamelin, B., Tisnerat-Laborde, N., Cabioch, G., 1998. Radiocarbon calibration by means of mass spectrometric ${ }^{230} \mathrm{Th} /{ }^{234} \mathrm{U}$ and ${ }^{14} \mathrm{C}$ ages of corals: An updated database including samples from Barbados, Mururoa and Tahiti. Radiocarbon 40, $1085-1092$.

Berger, A.L., 1978. Long-term variations of caloric insolation resulting from the earth's orbital elements. Quaternary Research 9, 139-167.

Betancourt, J.L., Latorre, C., Rech, J.A., Quade, J., Rylander, K.A., 2000. A 22,000-year record of monsoonal precipitation from northern Chile's Atacama Desert. Science 289, 1542-1546.

Bills, B.G., de Silva, S.L., Currey, D.R., Emenger, R.S., Lillquist, K.D., Donnellan, A., Worden, B., 1994. Hydro-isostatic deflection and tectonic tilting in the central Andes: Initial results of a GPS survey of Lake Minchin shorelines. Geophysical Research Letters 21, 293-296.

Blodgett, T.A., Lenters, J.D., Isacks, B.L., 1997. Constraints on the origin of paleolake expansions in the central Andes. Earth Interactions 1 (Available at http://EarthInteractions.org).

Blunier, T., Chappellaz, J., Schwander, J., Stauffer, B., Raynaud, D., 1995. Variations in atmospheric methane concentrations during the Holocene epoch. Nature 374, 46-49.

Bobst, A.L., Lowenstein, T.K., Jordan, T.E., Godfrey, L.V., Ku, T.-L., Luo, S., 2001. A $106 \mathrm{ka}$ paleoclimate record from drill core of the Salar de Atacama, northern Chile. Palaeogeography, Palaeoclimatology, Palaeoecology 173, 21-42.

Bond, G., Kromer, B., Beer, J., Muscheler, R., Evans, M.N., Showers, W., Hoffmann, S., Lotti-Bond, R., Hajdas, I., Bonani, G., 2001. Persistent solar influence on North Atlantic climate during the Holocene. Science 294, 2130-2136.

Cane, M., Clement, A.C., 1999. A role for the tropical Pacific coupled ocean-atmosphere system on Milankovitch and millennial timescales Part II: Global impacts. In: Clark, P.U., Webb, R.S., Keigwin, L.D. 
(Eds.), Mechanisms of Global Climate Change at Millennial Time Scales. American Geophysical Union, Washington, D.C., pp. 373-384.

Cross, S.L., Baker, P.A., Seltzer, G.O., Fritz, S.C., Dunbar, R.B., 2001. Late Quaternary climate and hydrology of tropical South America inferred from an isotopic and chemical model of Lake Titicaca. Bolivia and Peru. Quaternary Research 56, 1-9.

D’Agostino, K., Seltzer, G.O., Baker, P.A., Fritz, S.C., Dunbar, R., 2002. Late-Quaternary lowstands of Lake Titicaca (Peru/Bolivia): evidence from high-resolution seismic data. Palaeogeography, Palaeoclimatology, Palaeoecology 179, 97-111.

Fornari, M., Risacher, F., Feraud, G., 2001. Dating of paleolakes in the central Altiplano of Bolivia. Palaeogeography, Palaeoclimatology, Palaeoecology 172, 269-282.

Fritz, S.C., Juggins, S., Battarbee, R.W., 1993. Diatom assemblages and ionic characterization of lakes of the Northern Great Plains, North America: A tool for reconstructing past salinity and climate fluctuations. Canadian Journal of Fisheries and Aquatic Sciences 50, 1844-1856.

Gallup, C.D., Cheng, H., Taylor, F.W., Edwards, R.L., 2002. Direct determination of the timing of sea level change during Termination II. Science $295,310-313$.

Garreaud, R.D., Vuille, M., Clement, A.C., 2003. The climate of the Altiplano: observed current conditions and mechanisms of past changes. Palaeogeography, Palaeoclimatology, Palaeoecology 194, 5-22.

Grootes, P.M., Stuiver, M., 1997. Oxygen 18/16 variability in Greenland snow and ice with $10^{3}$ to $10^{5}$ year time resolution. Journal of Geophysical Research 102, 26455-26470.

Hastenrath, S., Kutzbach, J., 1985. Late Pleistocene climate and water budget of the South American Altiplano. Quaternary Research 24, $249-256$.

Hooghiemstra, H., Melice, J.L., Berger, A., Shackleton, N.J., 1993. Frequency spectra and paleoclimatic variability of the high-resolution $30-$ 1450 ka Funza I Pollen Record (Eastern Cordillera, Colombia). Quaternary Science Reviews 12, 141-156.

Kessler, A., 1984. The paleohydrology of Late Pleistocene Lake Tauca on the Bolivian Altiplano and recent climatic fluctuations. In: Vogel, J.C. (Ed.), Late Cainozoic Paleoclimates of the Southern Hemisphere. Balkema, Rotterdam, pp. 115-122.

$\mathrm{Ku}$, T.-L., 2000. Uranium series methods. In: Noller, J.M., Sowers, J.S., Lettis, W.R. (Eds.), Quaternary Geochronology: Methods and Applications. American Geophysical Union, Washington, DC, pp. 101-114.

Lenters, J.D., Cook, K.H., 1997. On the origin of the Bolivian high and related circulation features of the South American climate. Journal of Atmospheric Science 54, 656-677.

Lowenstein, T.K., Hein, M.C., Bobst, A.L., Jordan, T.E., Ku, T.-L., Luo, S., 2003. An assessment of stratigraphic completeness in climate-sensitive closed-basin lake sediments: Salar de Atacama, Chile. Journal of Sedimentary Research 73, 91-104.

Maslin, M.A., Burns, S.J., 2000. Reconstruction of the Amazon Basin effective moisture availability over the past 14,000 years. Science 290, 2285-2287.

Mayle, F.E., Burbridge, R., Killeen, T.J., 2000. Millennial-scale dynamics of southern Amazonian rain forests. Science 290, 2291-2294.

McManus, J.F., Oppo, D.W., Cullen, J.L., 1999. A 0.5-million-year record of millenial-scale climate variability in the North Atlantic. Science 283, 971-975.

Nobre, P., Shukla, J., 1996. Variations of sea surface temperature, wind stress, and rainfall over the tropical Atlantic and South America. Journal of Climate 9, 2464-2479.

Peterson, L.C., Haug, G.H., Hughen, K.A., Rohl, U., 2000. Rapid changes in the hydrologic cycle of the tropical Atlantic during the Last Glacial. Science 290, 1947-1951.

Prasad, A.K.S.K., 1990. The genus Cyclotella in Choctawatchee Bay, Florida with special reference to $C$. striata and C. choctawatchee. Phycologia 29, 418-436.

Robertson, A.W., Mechoso, C.R., Kim, Y.-J., 2000. The influence of Atlantic Sea surface temperature anomalies on the North Atlantic Oscillation. Journal of Climate 13, 122-138.

Seltzer, G., Rodbell, D., Burns, S., 2000. Isotopic evidence for late Quaternary climatic change in tropical South America. Geology 28, 35-38.

Servant, M., Fontes, J.-C., 1978. Les lacs quaternaires des hauts plateaux des Andes Boliviennes premieres interpretations paleoclimatiques. Cahiers de O.R.S.T.O.M., Series Geologie 10, 9-23.

Servant, M., Fournier, M., Argollo, J., Servant-Vildary, S., Sylvestre, F., Wirrmann, D., Ybert, J.-P., 1995. La derniere transition glaciaire/interglaciaire des Andes tropicales sud (Bolivie) d'apres l'etude des variations des niveaux lacustres et des fluctuations glaciaires. Comptes Rendus de l'Academie des Sciences, Paris, Series II 320, 729-736.

Smoot, J.P., Lowenstein, T.K., 1991. Depositional environments of nonmarine evaporites. In: Melvin, J.L. (Ed.), Evaporites, Petroleum, and Mineral Resources. Developments in Sedimentology Elsevier, Amsterdam, pp. 189-347.

Stocker, T.F., 2000. Past and future reorganizations in the climate system. Quaternary Science Reviews 19, 301-319.

Stuiver, M., Reimer, P.J., Bard, E., Beck, J.W., Burr, G., Hugen, K., Kromer, B., McCormack, F.G., Plicht, J.v.d., Spurk, M., 1998. INTERCAL98 radiocarbon age calibration 24,000 cal BP. Radiocarbon 40, 1041-1083.

Sylvestre, F., Servant, M., Servant-Vildary, S., Causse, C., Fournier, M., Ybert, J.P., 1999. Lake-level chronology on the southern Bolivian Altiplano $\left(18-23^{\circ} \mathrm{S}\right)$ during late-Glacial time and the early Holocene. Quaternary Research 51, 54-66.

Sylvestre, F., Servant-Vildary, S., Roux, M., 2001. Diatom-based ionic concentration and salinity models from the south Bolivian Altiplano (15-23 degrees South). Journal of Paleolimnology 25, 279-295.

Thompson, L., Davis, M.E., Mosley-Thompson, E., Sowers, T.A., Henderson, K.A., Zagorodnov, V.S., Lin, P.-N., Mikhalenko, V.N., Campen, R.K., Bolzan, J.F., Cole-Dai, J., Francou, B., 1998. A 25,000 year tropical climate history from Bolivian ice cores. Science 282, 1858-1864.

Vuille, M., Bradley, R.S., Keimig, F., 2000. Interannual climate variability in the Central Andes and its relation to tropical Pacific and Atlantic forcing. Journal of Geophysical Research 105, 12447-12460.

Wielicki, B.A., Wong, T., Allan, R.P., Slingo, A., Kiehl, J.T., Soden, B.J., Gordon, C.T., Miller, A.J., Yang, S.-K., Randall, D.A., Robertson, F., Susskind, J., Jacobowitz, H., 2002. Evidence for large decadal variability in the tropical mean radiative energy budget. Science 295, 841-844.

Zhou, J., Lau, K.-M., 1998. Does a monsoon climate exist over South America? Journal of Climate 11, 1020-1040. 